\title{
Analysis of Collaborative Learning Models in Online Thematic Learning During the Pandemic Covid-19
}

\author{
Oktiana Handini \\ Teacher Training and Education \\ Sebelas Maret University \\ Surakarta, Indonesia \\ Handinioktiana7@gmail.com \\ Gunarhadi \\ Teacher Training and Education \\ Sebelas Maret University \\ Surakarta, Indonesia
}

\author{
M Furqon Hidayatullah \\ Teacher Training and Education \\ Sebelas Maret University \\ Surakarta, Indonesia
}

\author{
Moch Akhyar \\ Teacher Training and Education \\ Sebelas Maret University \\ Surakarta, Indonesia
}

\begin{abstract}
Pandemic Covid-19 changes the test-face learning process into online learning, in this case, the teachers are required to be able to provide motivation and innovation of learning to the learners. This study aims to determine the effectiveness and inhibiting factors of collaborative and integrative thematic learning during the pandemic Covid-19 at SD Cluster II Surakarta City. This study uses a qualitative descriptive method with data collection techniques in the form of questionnaires, interviews, and documentation. By using the analysis of Miles and Huberman, namely: data reduction, data presentation, and concluding. The results of this study reveal that: first collaborative learning dominates more than integrative thematic learning. The two factors that become obstacles for teachers and students during the online learning process are internet networks, learning management, assessment, and supervision. The three collaborative learning are used as teacher actions to minimize learning problems during the pandemic covid19.
\end{abstract}

Keywords-Collaborative learning, integrative thematic learning, online learning

\section{INTRODUCTION}

The realization of quality education is the responsibility of all parties, especially the responsibility of implementing learning in schools. Ghani \& Wijayanti (2014) stated that education as a conscious and systematic effort by the government must be based on the reality of the Indonesian people and oriented towards efforts to prepare a young generation with character [1]. Education is a process of bringing about the desired changes in human behavior which can also be interpreted as a process of acquiring knowledge and habits through learning [2]. In-Law No. 20 of 2013 concerning the National Education system in Article 1 paragraph 1, which explains that education is a conscious and planned effort to realize learning and the learning process so that students actively develop their potential to choose religious-spiritual strength, education, intelligence, noble character, and skills needed by himself and the community, nation and state.

Education can always be divided into theory and practice, because education is a knowledge of the meaning and how education should be implemented, while practice is about the concrete (real) implementation of education [3]. The world of education is very important for a human being because education makes humans develop better in the future. Changes or developments in education are things that should happen in line with changes in the culture of human life. Changes in the sense of improving education at all levels need to be continuously carried out in anticipation of future interests with the demands of modern society. This of course concerns various fields, including the field of education. Education certainly has a learning design that will later be given to students or is often called a curriculum. The curriculum is a set of plans and regulations regarding the content and learning materials as well as the methods used as guidelines for the implementation of teaching and learning activities. Trianto (2010) In Indonesia, the 2013 curriculum has been implemented [4]. The development in the 2013 curriculum lies in the packaging which clarifies the process through thematic learning. Thematic learning is defined as learning that is designed based on certain themes so that it can provide experiences for students. In the discussion, the theme is reviewed from various subjects. Thematic is a 
symbol of all language lessons that facilitate students to productively answer questions that arise by themselves and satisfy curiosity with a natural appreciation of their surroundings.

However, the learning process which usually occurs classically face to face in the classroom has changed in the last few months since the outbreak of the Covid-19 virus which has spread to various countries including Indonesia [5]. All aspects of people's lives around the world are seriously affected by the coronavirus disease (Covid-19) pandemic or the new Sars-CoV 2 virus, which we already know as the Coronavirus outbreak or Covid-19. This virus outbreak first appeared on December 31, 2019, by the WHO China country office reporting a case of pneumonia of unknown etiology in the city of Wuhan, Hubei Province, China. The spread of this virus is quite fast between countries and throughout the world. On March 2, 2020, Indonesia reported 2 confirmed cases of Covid-19. Then on March 11, 2020, the World Health Organization (WHO) has declared this outbreak a global pandemic.

Education in Indonesia has also experienced such a huge impact due to the increasing number of Covid-19 cases in Indonesia, which has resulted in schools having to be closed starting from early childhood education to high school and even college. Based on the Circular Letter of the Minister of Education and Culture of the Republic of Indonesia Number 4 of 2020 regarding the implementation of education policies in the emergency period of the spread of coronavirus disease (Covid-19), the learning process from home is carried out with the following provisions: Learning from Home through online/distance learning, to provide a meaningful learning experience for students, without being burdened with the demands of completing all curriculum achievements for grade promotion and graduation. Previously the learning process was carried out face-to-face in the classroom, now the government has taken a new policy so that all teaching and learning activities in schools are replaced by distance learning or learning from home with online or online methods or offline or outside networks [5].

In the current pandemic, the implementation of the 2013 Curriculum demands the maximum role of teachers in the learning process even though they are online. The 2013 curriculum is thematic integrative which takes subject matter based on the theme by combining several lessons into one. Integrated thematic learning applied in elementary schools in the 2013 curriculum is based on Permendikbud Number 65 of 2013 concerning Standards for Primary and Secondary Education which states that "Following Graduate Competency Standards and Content Standards, the learning principles used are from partial learning to integrated learning. "Implementation of the 2013 curriculum in SD/MI is carried out through learning with an integrated thematic approach from Class I to Class VI. According to (Fatchurrohman, 2014)
Integrative thematic learning is learning that uses themes to link several subjects to develop students' affective, cognitive, and psychomotor aspects to provide meaningful learning [6]. The thematic term is used because the learning uses themes to relate several subjects, while the integrative term refers to the development of the child's entire totality which includes affective, cognitive, and psychomotor aspects. Yuliastri \& Sandy Ramdhani (2018) This integrative thematic learning emphasizes the integration of various subjects or disciplines that are connected to the themes that exist in the learning process [7]. Integrative thematic learning that combines various disciplines will direct the learning process and all the integration of these disciplines provides and is integrated into themes both interdisciplinary, interdisciplinary, multidisciplinary, and transdisciplinary

Changes in learning and teaching patterns will certainly never be separated from the role of the teacher. Collie (2011) especially changes to online learning patterns [8]. Teachers must be prepared for various learning conditions and student conditions, including the development of life in society [9]. For this reason, teachers need to use models to innovate in delivering integrative thematic learning online. Online learning is certainly different from face-to-face learning. Online learning focuses more on the accuracy and accuracy of students in receiving and processing online learning information [10]. Thematic learning is carried out online or online by utilizing social media in the delivery of learning materials [11]. Currently, especially since learning is done online, the learning method tends to be just passing on knowledge.

Interviews conducted by researchers with an elementary school teacher in the Cluster II area of Surakarta City obtained information that students lack the motivation to learn because online learning makes them bored. In online learning, students become less active in conveying their aspirations and thoughts, so that it can result in boring learning. A student who is bored in learning will make progress in his learning outcomes. Therefore, it is necessary to encourage students to be motivated to learn so that they can have learning achievements. The spirit of learning can be possessed by increasing communication and social interaction between students with one another. Various student personalities can be trained using collaborative learning to foster positive competition to achieve maximum learning outcomes. In today's very limited conditions, it takes understanding and creativity of teachers in packaging their online learning to attract the attention and motivation of students in following the stages of online learning. The selection of the right approach and model, as well as the support of various parties, determine the success of online learning. One of them is the collaborative learning model.

Collaborative learning allows a lot of added value, both for students and for teachers. These advantages 
include; 1) Students get the experience of collaborating not only with their classmates but with other students they have not previously known, 2) In collaborative learning, interactions between students they just know become focused because they follow a program that has been planned by the teacher, 3) Activities A collaborative nature will usually encourage motivation and a competitive spirit in a positive sense for students, 4) Students also get a lot of learning resources from teachers other than their school teachers who they have known so far [12]. Collaborative learning can provide opportunities to lead to successful practical learning practices. As technology for learning, collaborative learning involves the active participation of students and minimizes differences between individuals and has also added to the momentum of formal and informal education from two opposing forces, namely: 1) Realization of practice, 2) Raising awareness of social interaction to realize meaningful learning [13].

Collaboration skills are one of the 421 st century skills formulated by UNESCO, known as the 4Cs, which include; critical thinking, communication, creativity, and collaboration. Still, according to the ib. unesco portal, collaborative learning is a relationship among learners that fosters positive interdependence, individual accountability, and interpersonal skills. So collaborative learning is a relationship between students that fosters a positive attitude of interdependence, shows an attitude of responsibility for each individual, as well as interpersonal communication skills. Collaborative learning is a process in which students at various levels of ability (performance) work together in small groups towards a common goal.

Integrated thematic learning is possible if it is collaborative. Collaborative learning according to [14] is learning that is carried out in groups, but the goal is not to achieve the unity that is obtained through group activities. Students in groups are encouraged to find various opinions or thoughts issued by each individual in the group. Learning does not occur in unity, but learning is the result of diversity or difference. Law Number 20 of 2003 concerning the National Education System in article 3 formulates that: "National Education aims to develop the potential of students to become human beings of faith and fear of God Almighty, noble, healthy, knowledgeable, capable, creative, independent, and become democratic and responsible citizens". Thus, this study aims to describe a collaborative learning model in online thematic learning during the pandemic covid-19.

\section{METHOD}

This type of research is descriptive qualitative with a qualitative approach that aims to describe the effectiveness and constraints of collaborative learning in integrative thematic learning during the pandemic Covid-19. The research was conducted in Cluster II Elementary Schools, Kec. The Banjarsari of Surakarta
City include SDN Madyotaman, SDN Beskalan, SDN Bromantakan, SDN Ketelan, SDN Yosodipuro, SDN Temenggungan, SD Muhammadiyah 1, SD Al Khoir, SD Al Firdaus, SD IT Ibnu Qoyyim, and SD Kristen Triwindu. This research was obtained from the collection of relevant data and information by examining written sources such as scientific journals, reference books, literature, and other reliable sources. Data collection techniques in this study were obtained from questionnaires, interviews, and documentation. In this study, the credibility test was carried out by triangulation. In this study, the credibility test was carried out by triangulation. The data analysis technique using (Miles \& Huberman, 1992) which consists of three plots [15]. First, reduction. Data reduction is defined as the process of selecting, focusing on simplifying, extracting, and transforming rough data that emerges from written notes in the field. Data reduction takes place continuously as long as a qualitative research-oriented project takes place. The second presentation is a structured collection of information that provides the possibility of drawing conclusions and taking action. Third, concluding is an activity of a complete configuration. Conclusions were also verified during the study.

\section{RESUlTS AND DISCUSSION}

\section{A. Results}

21st Century In integrative thematic learning consists of Communication (communication), Collaboration (Collaboration), Critical Thinking (critical thinking), and Creativity (creativity) as well as providing theoretical clarity and a better understanding of learning. (Sanjayanti et al., 2020) explained that the research methodology module that integrates skills is Collaborative Learning feasible to use for the learning process [16]. Research methodology modules that integrate skills can increase student motivation in learning so that it has a positive impact on learning outcomes.

During online learning, the teacher innovates an appropriate model for students so that they are not saturated with integrated thematic learning online. This is done by the teacher to measure the extent to which students understand the learning material and this thematic learning emphasizes the integration of various subjects or disciplines that are connected to the themes in the learning process. (Ramdhani \& Yuliastri, 2018) explained that this integrative thematic learning that combines various disciplines will direct the learning process and all integrations from these disciplines provide and are integrated into themes both interdisciplinary, interdisciplinary, multidisciplinary, and transdisciplinary [17]. The results of using the model Collaborative Learning by elementary school teachers in the Cluster II area of Kec. Banjarsari Surakarta City can be described in Table 1. 
TABLE I. PERCENTAGE OF TEACHER INDICATORS USING MOdel Collaborative LEARNING

\begin{tabular}{|c|l|c|c|c|c|c|}
\hline \multirow{2}{*}{ No } & \multicolumn{1}{|c|}{ Indicator } & \multicolumn{5}{|c|}{ PercentageTeachers Class } \\
\cline { 3 - 7 } & & II & III & IV & V & VI \\
\hline 1 & $\begin{array}{l}\text { Communicating with an } \\
\text { activity to transfer } \\
\text { information both orally } \\
\text { and in writing }\end{array}$ & 100 & 93 & 100 & 75 & 81 \\
\hline 2 & $\begin{array}{l}\text { Collaborating with one } \\
\text { another to create a } \\
\text { conducive classroom } \\
\text { atmosphere }\end{array}$ & 87 & 75 & 93 & 81 & 75 \\
\hline 3 & $\begin{array}{l}\text { Understanding the } \\
\text { interconnections between } \\
\text { systems, compiling, } \\
\text { expressing, analyzing, } \\
\text { and solving problems }\end{array}$ & 93 & 93 & 100 & 93 & 87 \\
\hline 4 & $\begin{array}{l}\text { Skills in providing } \\
\text { variations of integrative } \\
\text { thematic learning }\end{array}$ & 80 & 70 & 100 & 80 & 75 \\
\hline
\end{tabular}

Table 1. shows that the percentage obtained from the use of the model Collaborative Learning by grade II to grade VI teachers. The percentage of teachers in grades III and VI is less good than teachers in grades II, IV, and IV. This can be seen from the indicator graphs between grade II and grade VI teachers using the model $.4 \mathrm{C}$.

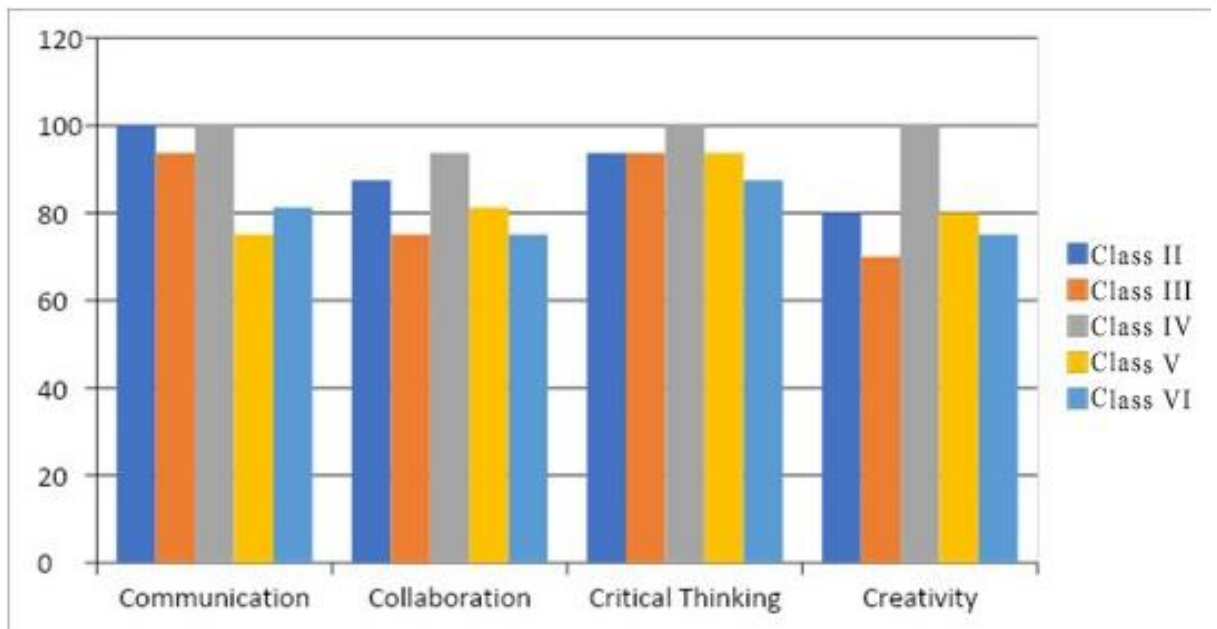

Fig. 1. Results of Using the model 4C.

The results of the graph above show that the use of the model for 4Cfourth grade teachers dominates over other classes. This can be seen from the results of the fourth-grade teacher questionnaire which stated: a) communicating with an activity to transfer information both orally and in writing $(100 \%)$, b) collaborating to create a conducive classroom atmosphere $(94 \%)$, c) understanding the interconnections between systems, compiling, expressing, analyzing, and solving problems $(100 \%), d)$ skills in providing variations of integrative thematic learning $(100 \%)$.

While the average use of the model for Collaborative Learning other teachers has a percentage of aa) communicating with an activity to transfer information both orally and in writing $(88 \%)$, b) collaborating to create a conducive classroom atmosphere $(80 \%)$, c) understanding the interconnections between systems, compiling, expressing, analyzing, and solving problems (92\%), d) skills in providing variations of integrative thematic learning $(76 \%)$. This result can be said that the fourth- grade teacher dominates using the model Collaborative Learning in integrative thematic learning. Based on the research questionnaire above, it can be said that the respondent answers that the use of the model is Collaborative Learning carried out by fourth-grade teachers better than other teachers.

\section{B. Discussion}

1) The Effectiveness of Collaborative Learning in Integrative Thematic Learning

The effectiveness of a learning model can be seen from the success of student learning outcomes in following the learning process, which includes three aspects, namely attitudes, knowledge, and skills. Learning in the 2013 curriculum has several basic competencies that must be mastered by students. Basic competence is the ability and minimum learning material that must be achieved by students for a subject in each educational unit that refers to core competencies. 
Collaborative Learning. This is in line with research (Wahyuni, n.d.) the benefits of collaborative learning include students feeling cared for because they find different ways to socialize and interact in a friendly and caring manner [18]. Therefore, the learning tools developed can improve the friendly character of students.

The researcher also obtained data for the results of the study by interviewing 5 (five) lower and upper-class students, teachers in grades I-VI with structured interview techniques to obtain accurate data to produce satisfactory results. Interviews with class II teachers or SMH mothers, third-grade teachers or AR mothers, IVgrade teachers or $\mathrm{W}$ and $\mathrm{W}$ teachers, fifth-grade teachers or AD mothers, and sixth-grade teachers or FR teachers took place in the teacher's room at the Elementary School Cluster II Kec. Banjarsari Surakarta and YI and DS as class III students, KN, ST, and AJ as class V students.

The results of the interviews showed that class IV teachers at SD Muhammadiyah 1 Ketelan Surakarta used the model Collaborative Learning in integrated thematic learning online more optimally than other teachers. in Cluster II Kec. Banjarsari, Surakarta City. The following are the results of the interview:

W: "Our strategy that has been used in distance learning the teacher uses an approach by communicating personally with students and working with parents in conditioning while learning during distance learning the teacher communicates personally with students to ensure that they can understand the material that has been delivered, submit assignments on time and provide feedback on the subject matter. Communication with parents is carried out as a way of assisting to inform the material and assignments submitted to students". (26 March 2021).

$\mathrm{W}$ : "In the learning process the teacher must familiarize his students with communicating with each other both about lessons and other matters, both with the teacher and with students. The language used by students in communicating will have an impact on the students themselves. The use of bad words in communication has a negative impact. In exploring information and constructing meaning, students need to be encouraged to collaborate with their classmates. In working on a product, students need to be taught how to appreciate each person's strengths and abilities and how to take on roles and adapt appropriately to them. One cannot study well without thinking well. Critical thinking is related to career success, but also success in higher education. Children's creativity can develop well if it is supported by several factors such as the following: providing good mental stimulation, creating a conducive environment, teacher participation in developing creativity, parental participation. creativity". (26 March 2021).
W: "Teachers must choose the most effective media from the various available media so that the media used in delivering material to students is the most appropriate with the learning objectives that have been formulated. The teacher's ability to convey material to students, the teacher must choose the learning media used following the abilities that exist in the teacher and students with a learning process that attracts attention. Teachers must be creative in providing learning media, for example by making their simple learning media or making them together with students". (26 March 2021).

$\mathrm{W}$ : "Yes, the online learning media most widely used is WhatsApp group. In WhatsApp groups, users can send various documents such as videos, photos, and even presentation files. So that group members can share material. Then there are the zoom learning media which is also used because by using the zoom media communication or there is the direct interaction between teachers and students". (26 March 2021).

Based on the results of interviews with fourth-grade teachers, it was found that fourth-grade teachers always provide learning videos and then send them to the What's App group so that students can study at home. Teachers teach technology to students so they don't miss out on online learning and motivate so that students are enthusiastic and don't get bored in participating in learning online. This can be explained following research conducted by (Sukitman \& Yazid, 2020) the spirit of learning cannot be separated from the role of teachers in facilitating their students to make it easier for the learning process during the pandemic [19]. Teachers must be able to adapt to the digital world so that learning can continue even in a pandemic. So, the role of the teacher cannot be replaced by anything even though at this time the digital era is needed in the learning process.

2) Constraints to Implementing Integrative Thematic Learning Using the $4 C$ Model During a Pandemic

The results showed that elementary school teachers in the Surakarta Cluster II area had difficulty managing learning in making teaching and learning processes effective online during the pandemic Covid-19. Moreover, there are disparities in the quality of education across regions of Indonesia, especially between Java and outside Java, and among socioeconomic conditions [20]. In addition, often complaining about the depletion of Internet quota can be a long learning process, so the quota that must be issued is also quite a lot. Assistance from the government is also deemed insufficient for students, the education quota can only be used for learning applications while students need to seek information from other applications. The following are the results of interviews with ST students:

ST: "It's a bit difficult because I can't listen to the explanation directly". (March 21, 2021). 
ST: "Sometimes the teacher explains through videos and sometimes uses questions". (March 21, 2021).

ST: "For the spirit of online learning, the teacher usually asks to sing the national anthem so that learning is not saturated and shows videos that help the learning material to be understood by students". (March 21, 2021).

ST: "The difficulty in learning online is that I have a large internet quota. If I don't have one, I go to a friend's house to sit side by side using WIFI to take part in learning online." (March 21, 2021).

Obligation to study at home is a serious obstacle for students because not all of them are economically well off. This is following the opinion of (Rigianti, 2020) regarding the Challenges of Online Learning During the Covid-19 Pandemic, it was explained that the sudden change in learning from face-to-face to online caused various responses and obstacles to the world of education in Indonesia [21]. except for the teacher who is the spearhead of education who directly deals with students. On average the benefits of online learning are much smaller than expected. An elementary school teacher in Cluster II district Banjarsari Surakarta City agrees that the most prominent obstacles are quotas, networks, and smartphones.

Meanwhile, the implementation of the model Collaborative has not run optimally. The Model is Collaborative Learning only limited to face-to-face group collaboration. The weaknesses of using the model Collaborative Learning include 1) Requires good supervision from the teacher, 2) There is a tendency to imitate the work of others, 3) Takes a long time, 4) It is difficult to find friends who can work together. The limitations of students are also found in exploring the thematic integrative learning ideas online. Ideally, it is hoped that in integrative thematic learning skills, it is Collaborative expected to be a carrying capacity for skills Creativity, Communication, and Critical Thinking.

3) Strategies to Overcome Obstacles inLearning Online

Applications Zoom, google meet, classrooms and other applications can make it easier for teachers to carry out teaching and learning activities for students. This is in line with Widyaningrum (2018) research on optimizing strategies for integrative thematic learning, which explains that the possible solutions are: 1) teachers can determine local culture and sort out materials to be integrated into local culture-based science learning, 2) learning resources what can be done in ethnoscience learning is the surrounding environment, literature, audio-visual, and the internet, and 3) teachers can use various methods in ethnoscience learning [22]. While research from Andarwulan (2021) teacher readiness and serious attention need to be urgently taken by education officials if the goal is to provide targeted and quality online learning to students in the fast-changing world [23]. In addition, teachers should organize more systematically in their pursuit of technology-based learning that they find most beneficial. The mechanism that has been implemented will certainly benefit the continuity of the education and training mission in times of crisis such as the current COVID (readiness of teachers and serious attention needs to be done by the education authorities if the goal is to provide online learning targeted and qualified to students are in a rapidly changing world. In addition, teachers must organize more systematically in pursuing technologybased learning which they think is the most useful. The mechanisms that have been implemented will certainly benefit the continuity of the education and training mission in times of crisis such as the current COVID).

Meanwhile, in the era of the pandemic covid-19, minimal learning planning includes; 1) selecting and determining the actions of educators, when and how to implement them, 2).limiting and determining the implementation of work according to learning targets, 3) learning strategy innovations, 4) analyzing situations and conditions to achieve learning implementation,.5) plans related to learning to the authorities. In other words, if a child learns, a change in the child's behavior can occur. Elementary school teachers' readiness for online learning can be measured by 6 indicators, such as availability of learning content, availability of technology tools, proficiency in applying technology tools, ability to purchase data packages, availability of internet access, and teacher attitudes towards online learning.

The use of technology can lead to creativity among students in developing the knowledge they already have and the varied learning of teachers can develop thinking through their analysis. Accordingly, Mondy (2008) may not have any technical factors that have a greater influence on training and development [24]. Technology has played a huge role in changing the way knowledge is conveyed to students, and this change continues. The advantages of using this model strategy Collaborative Learning include: 1) Students can learn deliberation or discussion with other students, 2) Students can respect the opinions of others. 3) Critical thinking can be developed in this model, 4) Develop cooperation in students to solve problems, 5) There is healthy competition. Strategies for elementary school class teachers in Cluster II Kec. Banjarsari Surakarta to optimize the integrated thematic learning model Collaborative Learning online has been good to give motivation at each process of learning.

\section{CONCLUSION}

Use of the model first collaborative grade teacher dominates compared to the use of models collaborative other classroom teacher learning online during the pandemic Covid-19. Teachers and students also explain the obstacles faced during the learning process online 
including learning applications, internet networks and devices, learning management, assessment, and supervision. The collaborative Learning learning model is very suitable to be used for the learning process in elementary schools.

The advantages of using this model strategy Collaborative Learning include: 1) Students can learn deliberation or discussion with other students, 2) Students can respect the opinions of others. 3) Critical thinking can be developed in this model, 4) Develop cooperation in students to solve problems, 5) There is healthy competition, within. Actions or actions taken by teachers and students to minimize the problems experienced by applying the learning model Collaborative Learning can link learning with one another with teaching aids. As well as conducting home visits for students who cannot participate in online learning. In addition to building good cooperation among students, this collaborative learning process can also open/ broaden students' horizons in viewing things from various scientific aspects/fields.

\section{ACKNOWLEDGMENT}

The authors would like to thank Drs. Sri Hartini, M.Pd as the dean of FKIP UNISRI who has allowed this research. The author also expresses his gratitude to the principal, teachers, and students in the Surakarta Cluster II area who are willing to be resource persons and help a lot so that the author can complete it in a relatively short time.

\section{REFERENCES}

[1] A. R. A. Ghani, \& A. T. Wijayanti. Generasi Penerus Bangsa Yang Berkarakter Dan Berakhlak Mulia *) Oleh Universitas Muhammadiyah Prof . DR . HAMKA ( UKD HEPI JABODETABEK ) Abstrak Perwujudan pendidikan yang berkualitas menjadi tanggung jawab semua pihak terutama menjadi tanggung jawab pela. September, 2014. 18-20.

[2] R. Ahmadi. Pengantar Pendidikan. Yogyakarta: Ar-Ruzz Media. 2016.

[3] I. Bernadib. Dasar-Dasar Kependidikan:Memahami Makna Dan Perspektif Beberapa Teori Pendidikan. Bogor: Galia Indonesia. 1996.

[4] Trianto. Pengembangan Model Pembelajaran tematik. Jakarta: Prestasi Pustakakarya. 2010.

[5] R. Seles, S. Halidjah, \& H. Kresnadi. Analisis Rencana Pelaksanaan Pembelajaran Tematik Secara Daring Selama Masa Pandemi COVID-19. Jurnal Pendidikan Dan Pembelajaran Khatulistiwa, 10(3), 2021. 1-9.

[6] Fatchurrohman. Tematik Integratif Konsep Dasar dan Aplikasi. 2014. 1-97. http://erepository.perpus.iainsalatiga.ac.id/2107/
[7] N. A. Yuliastri, \& S. Ramdhani. Pengembangan Pembelajaran Tematik Integratif Untuk. 3(1), 2018. 44-58. http://ejournal.hamzanwadi.ac.id/index.php/jga/article/view/898

[8] R. J. Collie, J. D. Shapka, \& N. E. Perry. Predicting Teacher Commitment: The Impact Of School Climate And SocialEmotional Learning. Wiley Periodicals, Inc, 48(10), 2011. 1034-1048. https://doi.org/10.1002/pits.20611

[9] R. Abdullah. Pembelajaran Dalam Perspektif Kreativitas Guru Dalam Pemanfaatan Media Pembelajaran. Lantanida Journal, 4(1), 2017. 35. https://doi.org/10.22373/lj.v4i1.1866

[10] C. Riyana. Produksi Bahan Pembelajaran Berbasis Online. Modul Pembelajaran Universitas Terbuka Tangerang Selatan, 2019. 1-43.

[11] R. Dian, P. Putri, \& V. V. Siregar. (n.d.). 1, 2, 3. 1-15.

[12] A. Koesnandar. Pembelajaran Kolaboratif di Era dan Pasca Pandemi, Mengapa Tidak? Pusat Data Dan Teknologi Informasi Kementerian Pendidikan Dan Kebudayaan. 2021. https://pusdatin.kemdikbud.go.id/pembelajaran-kolaboratifdi-era-dan-pasca-pandemi-mengapa-tidak/

[13] P. A. Lasidos, \& Z. Matondang. Penerapan Model Pembelajaran Kolaboratif Untuk Meningkatkan Aktivitas Dan Hasil Belajar Rencana Anggaran Biaya Siswa Kelas Xii Kompetensi Keahlian Teknik Gambar Bangunan Smkn 2 Siatas Barita - Tapanuli Utara. Educational Building, 1(1), 2015. 13-22. https://doi.org/10.24114/eb.v1i1.2802

[14] D. B. Widjajant. Strategi Pembelajaran Kolaboratif Berbasis Masalah. Semnas Matematika dan Pendidikan Matematika. 2008.

[15] Miles \& Huberman. Analisis Data Kualitatif. Universitas Indonesia Press. 1992

[16] N. P. A. H. Sanjayanti, N. W. S. Darmayanti, D. Qondias, \& K. O. Sanjaya. Integrasi Keterampilan 4C Dalam Modul Metodologi Penelitian. 3(3), 2020. 407-415.

[17] S. Ramdhani, \& N. A. Yuliastri. Model Pembelajaran Tematik Integratif Untuk Membentuk Karakter Jujur Anak Usia 5-6 Tahun. Jurnal Pelita Paud, 2(2), 2018. 149-150.

[18] M. Wahyuni. (n.d.). Pengembangan perangkat pembelajaran. 246-260.

[19] T. Sukitman, \& A. Yazid. Peran Guru Pada Masa Pandemi Covid-19. Prosiding Diskusi Daring Tematik Nasional, September, 2020. 91-95.

[20] Y. Azzizah. Socio-Economic Factors on Indonesia Education Disparity. International Education Studies, 8(12), 2015. 218. https://doi.org/10.5539/ies.v8n12p218

[21] H. A. Rigianti. Kendala Pembelajaran Daring Guru Sekolah Dasar Di Kabupaten Banjarnegara. Elementary School, 7(2), 2020. 297-302.

[22] R. Widyaningrum. Analisis Kebutuhan Pengembangan Model Pembelajaran Berbasis Etnosains Untuk Meningkatkan Kualitas Pembelajaran IPA Dan Menanamkan Nilai Kearifan Lokal Siswa Sekolah Dasar. Jurnal Widya Wacana, 13(2). 2018 .

[23] T. Andarwulan. Elementary Teachers 'Readiness toward the Online Learning Policy in the New Normal Era during Covid19. 14(3), 2021. 771-786.

[24] R. W. Mondy. Manajemen Sumber Daya Manusia. Jakarta: Penerbit Erlangga. 2008 